\title{
Sunflower Price Differentials Attributed to the Disparity of Traditional Cost Accounting and Conventional Methods in Tanzania
}

\author{
Godfrey Molela ${ }^{1, ~ *, ~ M o h a m e d ~ B a r a z a ~}{ }^{1}$, Lukelo Msese ${ }^{2}$, Mohamed Kaluse ${ }^{3}$, Felix Mlay ${ }^{4}$ \\ ${ }^{1}$ Department of Accounting and Finance, The University of Dodoma, Dodoma City, Tanzania \\ ${ }^{2}$ Department of Economics, The University of Dodoma, Dodoma City, Tanzania \\ ${ }^{3}$ Department of Accounting, Tanzania Institute of Accountancy, Singida Region, Tanzania \\ ${ }^{4}$ Department of Business Management, Institute of Accountancy Arusha, Arusha City, Tanzania
}

Email address:

godfrey.molela@udom.ac.tz (G. Molela)

*Corresponding author

\section{To cite this article:}

Godfrey Molela, Mohamed Baraza, Lukelo Msese, Mohamed Kaluse, Felix Mlay. Sunflower Price Differentials Attributed to the Disparity of Traditional Cost Accounting and Conventional Methods in Tanzania. Journal of Finance and Accounting. Vol. 9, No. 4, 2021 , pp. 111-116. doi: 10.11648/j.jfa.20210904.11

Received: January 11, 2021; Accepted: January 18, 2021; Published: July 6, 2021

\begin{abstract}
Sunflower is among the key cash crops in Tanzania, which contribute significantly to the country's economy. As it is the case for other crop subsectors, sunflower is also grown in abundance by smallholder farmers. Nevertheless, they had been living in poverty throughout their careers in agriculture which on the other hand benefited the counterparties in the trading deals. The unfair price offered to sunflower farmers was discovered in this study to be a misfortune in their investments. The conventional average farm-gate price of TZS. $622.449 / \mathrm{Kg}$ was found to be out of the price ranges that were backed by traditional cost accounting system, leaving farmers making losses of minimum TZS. 99.889/Kg. This study was conducted in Singida Region, Tanzania where a sample of 206 household farmers was used to obtain primary data on activity costs while the secondary data concerning the conventional price were obtained from the Districts' sales reports and farmers' records. Inferential statistics with one-sample test model was used alongside the IBM SPSS 26.0 statistical package in the quantitative data analysis. It was recommended, further studies to be conducted to explore more about the production cost that is backed by the activity-based costing (ABC) system, as it is more effective in assigning overheads to cost object than the traditional costing.
\end{abstract}

Keywords: Smallholder Farmers, Sunflower, Farm-Gate Price Range, Conventional Price, Traditional Cost Accounting, Activity-Based Costing (ABC)

\section{Background Information}

Sunflower is among the agricultural subsectors in Tanzania, which were prioritized by Capital Markets and Securities Authority (CMSA) in a move of operationalizing the commodity exchange market in the country [14]. This was however one of the strategies promulgated by the government through its ten pillars of kilimo kwanza "agriculture first", to enhance its performance through the coordination with the financial and industrial sectors, to work in a reciprocating manner [18]. The crop was grown in abundance in the central zones of the country characterized by dry weather condition including Dodoma, Singida, Tabora and Manyara regions [22, $31]$. Other areas with moderate production included some districts of Iringa and Morogoro regions [23].

Statistically, the subsector contributed about $36 \%$ in a pool of oilseeds in the country, ranked next to groundnuts subsector with about $40 \%$ contribution [1]. It was further reported in the study that, about 8 million of smallholder farmers engaged in the subsector, either directly through production or indirectly through the provision of labor force. More importantly, Tanzania was ranked among the top ten countries with the 
highest production of the crop in the world, contributing to about $2.4 \%$ to the world basket [29]. Nevertheless, the country still depended more on the imported edible oil because of the limited production of around 3 million metric tons, which was far below the planned annual volume of 10 million metric tons. Unreliable market, limited access to finance and the deficiency in technical knowhow were the eminent causes for the reported low production [21]. These were the same reasons that faced the generic poor performance of the small-scale farming in Tanzania [19]. This study focused on the market aspect to contribute to the research gap associated with the farm-gate pricing which forms the elementary part of the market structure.

Several studies have reported the mismatch of the returns and capital investment in small-scale farming, due to non-cost-reflective pricing strategies. It was revealed that, smallholder farmers themselves were the root cause of the problem in farm-gate pricing which is the determinant of market prices for agricultural products [6]. Cost accounting encompasses of techniques that are imperative for farmers to follow in order to produce the realistic farm-gate prices of the harvested crops $[8,12]$. However, they hardly implemented such recommended costing principles in their management accounting, hence ended up adopting the conventional means of pricing which is controlled by buyers [2]. This study was structured to answer the question, as to whether the range of farm-gate prices computed based on the traditional costing system includes the conventional average price. It based on the case of sunflower subsector in Singida Region, Tanzania and was grounded on the theory of profit maximization and value maximization with markup-pricing model used as the strategy in pricing.

\section{Literature Review}

\subsection{Empirical Literature}

Cost accounting is defined as the branch of management accounting that is meant to record, analyze, interpret and communicate the relevant costs to the management for internal uses, including the decision making [4]. There are different branches of cost accounting including, the process costing, joint and by-product costing, activity-based costing (ABC), standard costing and job order costing [12]. Traditional costing is defined as the cost accounting that involves the straightforward process of assigning the direct and indirect costs to cost object using a single cost driver [13]. While the direct costs are traced directly to cost object, all the indirect overhead costs are allocated to cost object using a multi-driver usually production volume or labor hour [10]. The production volume was the common cost driver that was normally used in traditional cost accounting for indirect cost assignment [8]. It was further added that, the precision of the system in cost measurement depends on the proportional amount of direct costs versus indirect costs [5]. The more the direct costs as compared to indirect costs, the more precise the measurement of cost object. Because of this flaw, the traditional costing should only be used when the firm is quite certain that most of its activities consume more of the direct costs than the indirect costs, otherwise the activity-based costing should be an alternative approach. However, the computed costs using the traditional costing in farming are more relevant used in the activity-based costing, signifying that the $\mathrm{ABC}$ starts where traditional costing ends [9].

The principal objective of cost accounting in farming has always been to determine the production expenses that are essential in determining the farm-gate prices of agricultural produces $[7,11]$. Farm-gate price is defined as the value of the agricultural produce sold at the farm place, which excludes other charges to be incurred if it was to be sold elsewhere apart from the farm compound [28]. Despite the recommendations to adopt the appropriate cost accounting in pricing, it was revealed that, smallholder farmers in Tanzania used tin as the measure of price for agricultural products on conventional basis [17]. Conventional price is defined in this study as the price average of agricultural produce offered by farmers to buyers of which its determination does not consider any principle of pricing as articulated in cost accounting. Similarly, it was discovered that, sacks were the other preferred tools to determine the conventional farm-gate price for the cocoa by the smallholder farmers in Tanzania [19]. The study further reported that, other smallholder farmers tended to determine farm-gate prices of produces even before the harvest, as they were driven by the need of immediate cash from buyers. Do the wholesale conventional farm-gate prices offered by sunflower smallholder farmers really reflected the costs incurred in the production? [20].

\subsection{Theoretical Literature}

This study was conducted based on the profit maximization theory, which states that, a firm always opts for the strategies that are meant to maximize profit while lowering costs in a short-run [30]. As the rule of thumb, profit is regarded as the subject of an upward change of income, measured by the relative increase of price against production cost [16]. Profit maximization theory encompasses elements of gross margin, which is analyzed by measuring the agribusiness profitability in terms of evaluating the amount of gross profit earned out of every shilling of sale proceeds [3, 27]. The costs under consideration in this measurement are those that change with the production volume including materials and direct labor costs, leaving aside the fixed costs [26]. In the course of determining the produce farm-price, this study employed also the elements of markup pricing method, which involves the addition of percentage as the profit on top of the production cost [25]. According to the study, markup percentage set-up always depended on the discretion of business owners after having assessed the customers' perception on prices. The percentage normally ranges from $20 \%$ to $50 \%$ in most of the businesses that adopted the pricing strategy. 


\section{Research Methodologies}

\subsection{Research Design and Approach}

The cross-sectional survey design was employed in this study to collect quantitative data from the widely dispersed smallholder sunflower households from Singida Region. This design was the appropriate means of obtaining a large amount of data from the widely scattered research units at one point in time [24]. The design worked efficiently in coherent with the quantitative research approach to obtain the relevant data from a sample of 396 households of which the heads of the family or the representatives were the units of inquiries. The sampling units were gathered from a population of 45,857 smallholder sunflower households using a simple random probability sampling technique without replacements. The computation of the sample size was based on the Yamane formula below:

$$
\begin{aligned}
n & =\frac{\mathrm{N}}{1+\mathrm{N}\left(e^{2}\right)}=\frac{45,857}{1+45,857\left(0.05^{2}\right)} \\
& =396.541 \approx 397 \text { Households }
\end{aligned}
$$

\section{Where;}

$n=$ Sample size,

$N=$ Population size (National Bureau of Statistics [NBS], 2007),

$e=$ Level of significance $(1-$ Confidence Interval $(\alpha=$ $95 \%)$

In addition to the cross-sectional survey design, the study also employed the descriptive research design, which was essential to give the explanations of the variables in question that defined the sunflower farm-gate price [15]. Such variables include farm rent, farm preparation, input seeds, planting, weeding, manure/fertilizer application, rodent/birds control, harvesting and transport to storage. They were all measured in Tanzanian shillings (TZS) by considering magnitude of their impact on the amount of the total production cost which is of vital importance in the gross margin analysis.

\section{2, Quantitative Data Analysis}

The study analysis was executed using inferential statistics based on the parametric model defined by such parameters of central tendency. With the aid of IBM SPSS statistical package 26.0 both primary and secondary data were summarized to get mean for comparison purpose. Data were collected using such techniques including structured questionnaire, interview based on the structured questionnaire and documentary review. The validity of the collection tools and the reliability of data were ensured, by firstly developing a draft questionnaire which was then submitted to experts for review and subsequently tested in the field before a final revised tool was produced [24]. Likewise, data screening was done while filling the figures in the software by removing the repeated information and the outliers.

The ultimate purpose of performing inferential statistical analysis was to draw an inference on to whether the average price charged by smallholder sunflower farmers on sunflower seeds fell within the price range due to traditional costing system. The inference was made based on the null hypothesis below:

$H_{0}$ : The mean population of conventional sunflower price is different from the mean sample of traditional costing backed sunflower price.

Mathematically, $H_{0}: \ddot{X} \neq \mu$, or $H_{0}: \ddot{X}-\mu \neq 0$

Procedures taken in the Quantitative Data Analysis:

Procedure I: Summarized the data of conventional sunflower prices into central tendency parameters, using the mean formula below;

$$
\mu=\frac{\sum_{i=1}^{N} X_{i}}{N}
$$

Where; $\mu=$ Population Mean, $X_{i}=$ Variables, $\mathrm{N}=$ Population Units

Procedure II: Using a One-Sample Test to compute the confidence interval of the traditional costing-backed sunflower price, using the formula below;

$$
\ddot{\mathrm{X}} \pm t_{n-1} \frac{S}{\sqrt{n}}
$$

Where; $\ddot{X}=$ Sample Mean, $t_{n-1}=1.9716$ with degree of freedom n-1 $=205, S=$ Sample Standard Deviation and $n=$ Sample Units.

Procedure III: Accepting or rejecting the Null Hypothesis

The null hypothesis, Ho: $\ddot{X} \neq \mu$, would be accepted if the population mean $(\mu)$ fell within the non-rejection region of the sample mean $(\ddot{X})$, otherwise it would be rejected.

\section{Research Findings and Discussion}

\subsection{Research Findings}

Primary data on the direct and indirect costs were collected from 206 households, which represented $52 \%$ of the expected sample size (397 households). Out of 206 households, 139 (67\%) households responded to research questions by filling the structured questionnaires, while 67 (33\%) households provided their answers to questions through the structured interviews conducted on individual basis. Based on the parameters of the traditional costing in small scale farming operations, the units of inquiries were asked to provide the estimates on both direct and indirect costs incurred to run a one acre sunflower farm in a single season. According to the crop calendar, the season lasts from November where farmers start the farm preparation through July where the crop is finally harvested. Other cost activities during the season include input seeds purchase, planting, weeding, manure/fertilizer application, birds/rodents control and storage.

Table 1 below shows the direct costs that include input seeds, planting, harvesting and storage bags that were categorized so because of their traceability to the total 
production cost, where they each contributed $6 \%, 11 \%, 25 \%$ and $11 \%$ respectively.

Table 1. Activity costs.

\begin{tabular}{|c|c|c|c|c|c|c|c|c|c|c|}
\hline Particulars (TZS) & $\begin{array}{l}\text { Farm } \\
\text { Rent }\end{array}$ & $\begin{array}{l}\text { Farm } \\
\text { Preparation }\end{array}$ & $\begin{array}{l}\text { Input } \\
\text { Seeds }\end{array}$ & Planting & Weeding & $\begin{array}{l}\text { Manure/ } \\
\text { Fertilizer }\end{array}$ & $\begin{array}{l}\text { Birds/Rodents } \\
\text { Control } \\
\end{array}$ & Harvesting & $\begin{array}{l}\text { Storage } \\
\text { Bags }\end{array}$ & Total \\
\hline Total|All Respondents "000" & 2,525 & 3,790 & 2,978 & 5,535 & 3,777 & 3,784 & 9,875 & 12,395 & 5,309 & 49,968 \\
\hline Average|Mean (苂/Acre) "000" & 12.257 & 18.398 & 14.456 & 26.869 & 18.335 & 18.369 & 47.937 & 60.170 & 25.772 & 242.563 \\
\hline 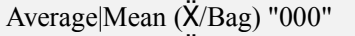 & 2.451 & 3.680 & 2.891 & 5.374 & 3.667 & 3.674 & 9.587 & 12.034 & 5.154 & 48.513 \\
\hline Average|Mean (艾/Kg) "000" & 0.035 & 0.053 & 0.041 & 0.077 & 0.052 & 0.052 & 0.137 & 0.172 & 0.074 & 0.693 \\
\hline Standard Deviation (S) "000" & 6.322 & 3.713 & 2.706 & 3.213 & 1.450 & 7.406 & 23.105 & 5.655 & 4.096 & 37.102 \\
\hline
\end{tabular}

Source: Researchers' Own Collected Data.

Apart from the direct costs, the table also includes, the indirect costs such as rent, preparation, weeding and birds/rodents control, which could hardly be associated with the production cost, where they each contributed $5 \%, 8 \%, 7 \%$ and $20 \%$ to cost object respectively. Such research results from the primary sources, which were analyzed to produce the average farm-gate price that is backed by traditional costing, were subsequently compared with the average conventional farm-gate price (TZS. $622.449 / \mathrm{Kg}$ ) which was due to secondary sources of data.

The sales reports from the respective districts showed the variation of conventional prices from TZS. 25,000 per a bag of $70 \mathrm{Kgs}$ when the seasons started to TZS. 60,000 per bag when the season were at peak. In between the beginning and peak of the season, the reported prices were TZS. 30,000; TZS. 40,000; TZS. 45,000; and TZS. 55,000 per a bag of $70 \mathrm{Kgs}$. This variation of prices made an average price of TZS. 43,571.43 per a bag of $70 \mathrm{Kgs}$.

The percentage contributions of the activity costs to cost object are summarized in the pie chart below.

\subsection{Research Analysis and Discussion}

After having obtained the average conventional price, the price range of farm-gate prices backed with traditional costing were computed as well, for testing purpose as shown in the table The table shows testing results of the hypothesized relationship between the sunflower farm-gate price-backed by traditional costing system and the average conventional price during the entire season. The conventional price (TZS. $622.449 / \mathrm{Kg}$ ) fell outside the confidence intervals due to different ranges of markup price percentages, hence led to drawing an inference that the sunflower conventional price was not cost reflective as far as traditional costing is concerned.

For smallholder sunflower farmers who planned to realize a profit of $5 \%, 10 \%, 20 \%, 30 \%, 40 \%$ and $50 \%$ out of their investment capital, would rather end-up suffering a loss amounting to TZS. TZS. $99.889 / \mathrm{Kg}$, TZS. $134.286 / \mathrm{Kg}$, TZS. $203.08 / \mathrm{Kg}$, TZS. $271.874 / \mathrm{Kg}$, TZS. $340.668 / \mathrm{Kg}$ and TZS. $409.462 / \mathrm{Kg}$ respectively. These losses were contrary to the maximum expected profits of TZS. $110.592 / \mathrm{Kg}$, TZS. $145.499 / \mathrm{Kg}$, TZS. $215.312 / \mathrm{Kg}$, TZS. $285.125 / \mathrm{Kg}$, TZS. $354.939 / \mathrm{Kg}$ and TZS. $424.752 / \mathrm{Kg}$ to be brought about by markup price percentages of $5 \%, 10 \%, 20 \%, 30 \%, 40 \%$ and $50 \%$ respectively. The quantitative actual losses suffered by sunflower farmers versus the expected profits are as summarized table below:

Table 2. Null hypothesis test results.

\begin{tabular}{|c|c|c|c|c|c|c|}
\hline $\mathbf{S} / \mathbf{N}$ & Tail & $\begin{array}{l}\text { Confidence Interval - Cost } \\
\text { Object (TZS/Kg) }\end{array}$ & Markup Price (\%) & $\begin{array}{l}\text { Confidence Interval -Price by } \\
\text { Traditional Costing (TZS/Kg) }\end{array}$ & $\begin{array}{l}\text { Average Conventional } \\
\text { Price (TZS/Kg) }\end{array}$ & $\begin{array}{l}\text { Null Hypothesis } \\
\text { Test "Ho: } \ddot{X} \neq \mu \text { " }\end{array}$ \\
\hline \multirow{2}{*}{1} & Lower & 687.941 & \multirow{2}{*}{$5 \%$} & 722.338 & \multirow{2}{*}{622.449} & Failed to be \\
\hline & Upper & 698.134 & & 733.041 & & Rejected \\
\hline \multirow{2}{*}{2} & Lower & 687.941 & \multirow{2}{*}{$10 \%$} & 756.735 & \multirow{2}{*}{622.449} & Failed to be \\
\hline & Upper & 698.134 & & 767.948 & & Rejected \\
\hline \multirow{2}{*}{3} & Lower & 687.941 & \multirow{2}{*}{$20 \%$} & 825.529 & \multirow{2}{*}{622.449} & Failed to be \\
\hline & Upper & 698.134 & & 837.761 & & Rejected \\
\hline \multirow{2}{*}{4} & Lower & 687.941 & \multirow{2}{*}{$30 \%$} & 894.323 & \multirow{2}{*}{622.449} & Failed to be \\
\hline & Upper & 698.134 & & 907.574 & & Rejected \\
\hline \multirow{2}{*}{5} & Lower & 687.941 & \multirow{2}{*}{$40 \%$} & 963.117 & \multirow{2}{*}{622.449} & Failed to be \\
\hline & Upper & 698.134 & & 977.388 & & Rejected \\
\hline \multirow{2}{*}{6} & Lower & 687.941 & \multirow{2}{*}{$50 \%$} & $1,031.911$ & \multirow{2}{*}{622.449} & Failed to be \\
\hline & Upper & 698.134 & & $1,047.201$ & & Rejected \\
\hline
\end{tabular}

Source: Researchers' Own Collected Data and District Sunflower Sales Reports.

Table 3. Losses suffered by sunflower farmers at different profit expectation levels.

\begin{tabular}{|c|c|c|c|c|c|c|}
\hline \multirow[b]{2}{*}{ Particulars } & \multicolumn{6}{|c|}{ Markup Price Percentages } \\
\hline & $5 \%$ & $10 \%$ & $20 \%$ & $30 \%$ & $40 \%$ & $50 \%$ \\
\hline Minimum Price (TZS/Kg) & 722.338 & 756.735 & 825.529 & 894.323 & 963.117 & $1,031.911$ \\
\hline Maximum Expected Profit (TZS/Kg) & 110.592 & 145.499 & 215.312 & 285.125 & 354.939 & 424.752 \\
\hline Minimum Loss Suffered (TZS/Kg) & 99.889 & 134.286 & 203.080 & 271.874 & 340.668 & 409.462 \\
\hline
\end{tabular}

Source: Researchers' Own Collected Data and District Sunflower Sales Reports. 


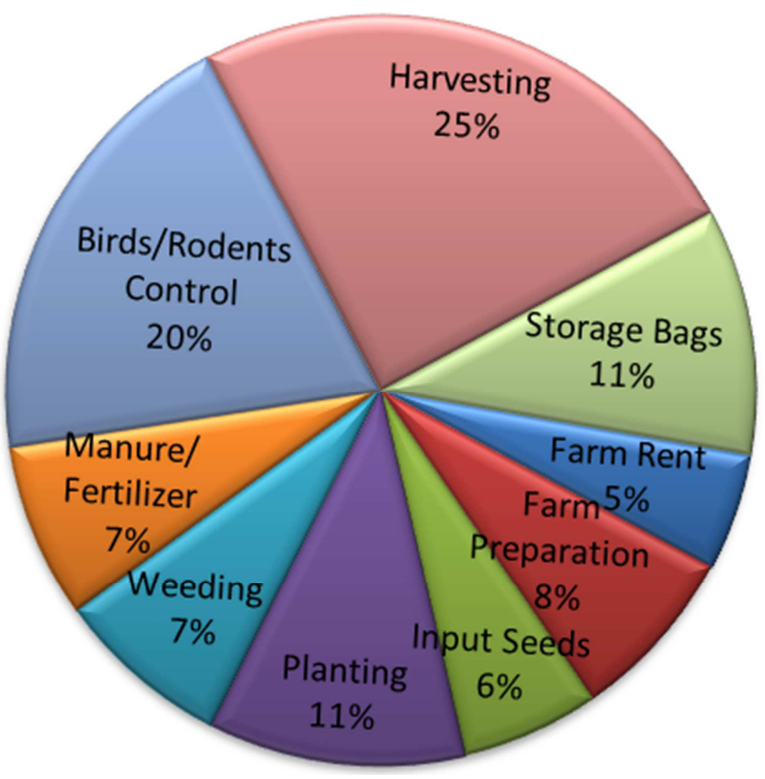

Source: Researchers' Own Collected Data.

Figure 1. Pie chart showing the percentage distribution of cost object.

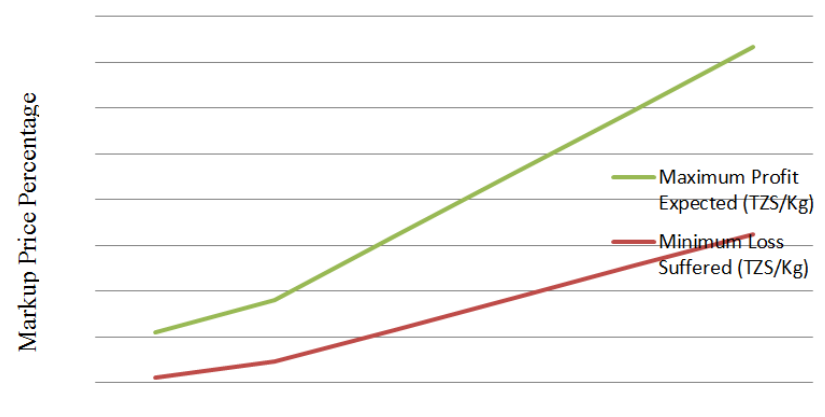

Expected Profit versus Loss Suffered (TZS/Kg)

Figure 2. Relationship between the expected profit versus and losses suffered.

The results show that, the more the profit expected out of the sale proceeds, the more the loss to be suffered by the smallholder sunflower farmers. The minimum loss suffered was TZS. 99.889/Kg and TZS. 409.462/Kg which were due to the expectations of $5 \%$ and $50 \%$ profit on top of the production cost respectively. The observed relationship between the expected profits and the loss suffered versus markup price percentage showed an upward trend. This relationship is summarized in the following OGIVE graph with expected profits and losses suffered in the $x$-axis while markup price percentage being at $y$-axis.

\section{Conclusion and Recommendations}

\subsection{Conclusion}

It was concluded that, the average farm-gate price of TZS. $622.449 / \mathrm{Kg}$ was not fairly charged on sunflower business conducts as it left smallholder sunflower farmers making losses. Depending on the magnitude of the profit expected, farmers were urged to set farm-gate price that would cover the average production cost of TZS. 687.941/Kg. Having understood the activity costs for different departments, farmers can as well strive to reduce costs for some activities in a move of boosting profit. The activities that consumed more cost in small-scale sunflower production include harvesting (25\%), birds/rodents control (20\%) and storage bags (11\%).

\subsection{Recommendations}

It was likewise recommended that, more studies had to be conducted to determine the production cost of sunflower seeds that is backed by activity-based costing ( $\mathrm{ABC}$ ) system. ABC is the most accurate cost accounting for the determination of cost object in the farming businesses [8]. The two systems however work simultaneously, in the sense that traditional costing is used to determine the activity costs for assignment purpose at the $\mathrm{ABC}$ using the appropriate cost drivers. With this regard, farmers will be at a better position to realize the potentiality of their commitments in farming businesses.

\section{Acknowledgements}

Researchers express their gratitude to the office of Prime Minister, Tanzania which through the program of Market Infrastructure, Value Addition and Rural Finance (MIVARF) made it possible the collection of primary data. Heartfelt thanks are also extended to the office of Singida Regional Administrative Secretary (RAS), District Executive Directors (DED) for Manyoni and Itigi Councils for their material support and ideas to get this work done.

\section{References}

[1] Anderson, J., Marita, C., \& Musiime, D., 2016. National Survey and Segmentation of Smallholder; Understanding Their Demand for Financial, Agricultural,. Working Paper, 1 - 118.

[2] Antonaci, L., Demeke, M., \& Vezzani, A., 2014. The challenges of Mananging Agricultural Price and Production Risks in Sub-Saharan africa. ESA Working Paper No. 14 - 09, $14(09)$.

[3] Bennett, A., 2014. Users Guide to Gross Margin Analysis. https:dpipwe.tas.gov.au (accessed 4 March 2020).

[4] Borad, S., 2019. Cost - Costing - Cost Accounting - Cost Accountancy. eFinanceManagement.com (accessed 4 March 2020).

[5] Bragg, S., 2018. Traditional Costing. Accounting Tools: Accounting CPE Courses \& Books. accountintools.com (accessed 5 March 2020).

[6] Courtois, P., \& Subervie, J., 2014. Farmer Bargaining Power And Market Information Services. American Journal of Agricultural Economics, 97 (3).

[7] Davenport, H., 1919. Farm Products and Costs Accounting. Journal of Political Economy, 27 (5), 354 - 361.

[8] Drury, C., 2017. Management and Cost Accounting (10 ${ }^{\text {th }}$ ed.). Cengage Learning. United Kingdom. 
[9] Fisher, T., 2012. Cost Accounting Applied to Farming in Southwest Michigan. Honors Theses, 2320.

[10] Gaille, B., 2018. 13 Traditional Costing System Advantages Disadvantages. Brandongaille: Small Business and Marketing Advice. brandongaille.com (accessed 5 March 2020).

[11] Harper, J., Cornelisse, S., Kime, L., \& Hyde, J., 2019. Agricultural Alternatives: Budgeting for Agricultural Decision Making. PennState Extension, United States.

[12] Horngren, C., Datar, S. \& Rajan, M., 2018. Cost Accounting: A Managerial Emphasis (15 ${ }^{\text {th }}$ ed.). Pearson Education, Inc. United States of America.

[13] Huang, Q., 2018. Skylar, Inc.: Traditional Cost System vs. Activity-Based Cost System - A Managerial Accounting Case Study. Applied Finance and Accounting, 4 (2), 55 - 66.

[14] Massinda, N., 2017, June 30. Annual Report: 2016 - 2017. Annual Report.

[15] McCombes, S., 2019. Descriptive Research. coursehero.com (accessed 10 March 2020).

[16] Missouri Economic Research Center and Information Center, 2016. Economic Contribution of Agribusiness. Department of Economic Development. Missouri, United States of America.

[17] Mkenda, B. K., \& Campenhout, B., 2011. Estimating Transaction Costs in Tanzanian Supply Chains. Working Paper 11 (0898), 1 - 48. https://www.theigc.org (accessed 8 March 2020).

[18] Mkonda, M. \& He, X., 2016. Efficacy of Transforming Agriculture for Survival to Commercial Agriculture through 'Kilimo Kwanza' Initiative in Tanzania. Natural Resources and Conservation, 4 (4), 43 - 50. Doi: 1013189/nrc.2016.040401.

[19] Molela, G., 2017. Capital Markets Financing for Agricultural Business Development in Tanzania; A Case of Cocoa Farming in Kyela and Rungwe Districts. Journal of Entrepreneurial Finance, 18 (5).

[20] Namwata, B., \& Baha, M., 2018. Producer Empowerment and Market Linkage: Sunflower Subsector. The United Republic of Tanzania: Prime Minister's Office, Market Linkage Value addition and Rural Finance. Dodoma: Mellon Consults (T) Ltd.

[21] Mwang'onda, E. S., Mwaseba, S. L., \& Juma, M. S., 2018.
Industrialisation in Tanzania: The Fate of ManufacturingSector Lies upon Policies Implementations. International Journal ofBusiness and Economics Research, 7 (3), 71-78.

[22] National Bureau of Statistics (NBS), 2016. National Sample Census of Agriculture. Dar es Salaam: The United Republic of Tanzania (URT).

[23] Ndondole, E., 2014. Sunflower Value Chain Development in Tanzania: The case of SHADECO in Village Based Contract Farming Arrangement in Iringa Region -Tanzania. A Presentation at Multi-Stakeholder Conference on Agricultural Investment Gender and Land in Africa. Capetown- Rsa, 5-7 March 2014.

[24] Njiku, A., 2019. Determinants of Technical Efficiency and Financial Sustainability of Small Scale Sunflower Oil Processing Firms in Tanzania. PhD Thesis, Mzumbe University. Tanzania.

[25] Nkonya, N., \& Cameron, A., 2015. Analysis of Price Incentives for Cashew nuts in the United Republic of Tanzania $2005-$ 2013. Food and Agriculture Organization of United Nations. Rome.

[26] Osterhaus, E., 2019. Financial Management: How to run a Gross Margin Analysis for your Small Business. quickbooks.intuit.com (accessed 6 March 2020).

[27] Rural Solutions SA, 2015. Farm Gross Margin Guide 2015: A Gross Margin Template for Crop and Livestock Enterprises. https://grdc.com.au/Resources/Publications (accessed 9 March 2020).

[28] Russo, C. \& Goodhue, R., 2017. Farm-gate Prices, Retail Prices and Supermarkets' Pricing Decisions: An Integrated Approach. Agribusiness: Wileyonlinelibrary.com, 34 (3), 24-43.

[29] The United Republic of Tanzania, 2016. Tanzania Sunflower Strategy 2016 - 2020. Retrieved from www.mit.go.tz.

[30] Tripathi, A., 2019. Profit Maximization Theory and Value Maximization Theory. International Journal of Scientific Development and Research (IJSDR), 4 (6), 284 - 289.

[31] Zhihua Zeng, D., 2011. The Sunflower Sector in Tanzania - A Great Potential for Industrial Competitiveness. Retrieved from www.tzdpg.or.tz. 